\title{
Ivan Baruch Kutisker in Finland
}

\author{
Initial encounters with Finnish antisemitism \\ before the Great German Scandal
}

\section{André SWAnströM}

AвstRAct - Ivan Baruch Kutisker was a Lithuanian Jewish businessman who became a prominent symbol of Nazi propaganda and antisemitism in the Weimar Republic. Before Kutisker came to Germany he had a brief engagement as the Finnish government representative to Soviet Russia. This article contributes to the research on Kutisker as well as to the research on antisemitism in Finland. Ivan Kutisker's sojourn in Finland has been an unknown chapter in his life. Kutisker's contact persons in Finland were Heikki Renvall, Kai Donner and K. N. Rantakari. The attitudes displayed by Renvall, Donner and Rantakari indicate that antisemitism was widespread among the Finnish political and military establishment. The article illustrates how antisemitism influenced the thinking and decision-making of high-ranking Finnish officials.

Ivan Baruch Kutisker was a Lithuanian Jewish businessman who became a prominent symbol of Nazi propaganda and antisemitism. Nazi propaganda portrayed him as an archetypal eastern Jewish crook exploiting the weak Weimar Republic. Before Kutisker came to Germany he had a brief engagement as a Finnish government representative to Soviet Russia. This engagement entailed both trust and suspicion, as the Finnish authorities displayed ambivalent attitudes, ranging from acceptance to outright antisemitism. This article probes Kutisker's problematic encounters with representatives of the Finnish political establishment. I will begin with a brief outline of Finnish antisemitism, then I will go on to present Kutisker's arrival in Finland and his encounters with Heikki Renvall, Kai Donner and K. N. Rantakari, three prominent members of the Finnish political establishment. These encounters culminated in a controversy between Kutisker and Rantakari at the Russo-Finnish border. From there I will go on to examine the development of Renvall's and
Rantakari's attitudes towards Jews in order to understand their actions. Finally I will present the turns of fate that made Ivan Kutisker into an icon of Nazi propaganda. My research is guided by the following questions: How did people in the Finnish political establishment treat Ivan Kutisker? How did they relate to Jews and antisemitism in general? What do their attitudes regarding Kutisker tell us about the Finnish political and military elites and their opinions on Jews and antisemitism?

\section{The Finnish antisemitic context}

Jewish settlement in Finland became possible in the late I85os when Tsar Alexander II granted discharged Jewish soldiers the right to settle in Finland after they had completed their military service. Jewish civil rights gradually became a political issue in Finland, and a parliamentary debate started to evolve during the last decades of the nineteenth century. Representatives of the clergy and the peasants voiced some of the 
most vicious antisemitic outbursts in the debate. Mikael Enckell regards the debate as a manifestation the paranoid collective delusion of antisemitism, which was rooted in Finnish society (Enckell I993: 38). Owing to persistent opposition and legal technicalities the issue of Jewish civil rights remained unresolved until Finland gained independence. Jews were granted civil rights in I9I8, but at the same time antisemitism was on the rise. Finnish antisemitism received intellectual impulses from both German völkisch-style antisemitism and the Russian antisemitic tradition (Forsgård 2002: I I). The Russian Revolution sparked conspiracy theories, blaming Jews for the revolution and accusing them of even wider aspirations for global domination. The most vocal Finnish antisemites were active in small far-right groups promoting publications such as the Finnish and Swedish translations of The Protocols of the Elders of Zion (Laitila 2014: I30-64). Jari Hanski has suggested that antisemitism was a marginal phenomenon in Finland during the interwar era (Hanski 2006: 404-13). This view has been challenged by Simo Muir. He argues that Finnish historians have tended to ignore, understate or deny Finnish antisemitism (Muir 2013). ${ }^{1}$

Recent research has indicated that antisemitism was not a marginal phenomenon in Finland during the I 920 and the I 930 s. For example, the leadership of the Finnish Evangelical Lutheran Church, with a few exceptions, endorsed overtly antisemitic opinions (Ahonen 201 7: 324-9). A major surge in Finnish antisemitism occurred in connection with the Russian Revolution, and the notion of Bolshevism as a Jewish phenomenon was widely accepted in bourgeois circles. Ivan Kutisker's engagement as a Finnish government representative thus took place at a time when antisemitism was on the rise in Finland.

1 For a summary of research on Finnish antisemitism, see Ahonen 201 7: I6-I 9.

\section{Kutisker comes to Finland}

At the end of the Finnish Civil War in 1918 the situation at the border between Finland and Russia was highly volatile. Finland had gained independence in December I9I7 and subsequently recognition from the Bolshevik government. The Bolsheviks nevertheless showed an interest in the Finnish Civil War, which broke out in January I9 8 . The Finnish revolutionaries received arms and military aid from Russian soldiers stranded in Finland after the declaration of independence. Finnish government troops, aided by the German Ostseedivision, were able to quell the red uprising, and in May r 9r 8 the Civil War was over. The issue of establishing a border between Finland and Soviet Russia was, however, yet to be solved. Finnish policy aimed to create a sealed border and severing all ties with the Bolshevik entity, which was regarded as a continuous threat to Finnish independence. This policy was in conflict with vital commercial interests. Trade between Finland and Russia had been a mutually beneficial deal, and Finland was heavily dependent on import from Russia.

This prompted the Finnish Trade and Industry Commission to use the services of a Lithuanian Jewish businessman named Ivan Baruch Kutisker (1873-1927). Kutisker had a background as a supplier to the Russian army, and this fact seemed to boost his credibility. He presented himself as a businessman with excellent contacts in Russian government circles and managed to convince key officials in Helsinki that he was the right person for the task. ${ }^{2}$

2 Kutisker can be compared with Olof Aschberg, a Jewish banker from Sweden who negotiated with the Bolshevik leadership on behalf of the Swedish government. The negotiations combined trade issues with political recognition of the Bolshevik government (Carlbäck-Isotalo I 997: I 23, 26I). Like Kutisker, Aschberg made an inter- 
However, the Finnish border authorities viewed Kutisker with suspicion, and their attitudes betrayed ill-concealed antisemitism. Kutisker's assignment as a semi-official Finnish trade and diplomatic representative was brief and swathed in controversy, and he was quick to relocate to Germany in I919, where he apparently sensed better opportunities. In Berlin he was entangled in financial affairs, which evolved into the so-called Kutisker-Barmat scandal. Kutisker, together with the Barmat brothers, was accused of defrauding millions of Reichsmarks from the Prussian State Bank, and as Ostjuden (Jews from Eastern Europe), they became symbols of alleged Jewish criminality in Nazi propaganda. Kutisker's sojourn in Finland has so far not received any scholarly attention. The consolidation of the border between Finland and Russia constitutes the context of Kutisker's engagement in Russo-Finnish affairs. The events at the border between I9I 8 and I920 have been studied in depth by Max Engman (2008), but he does not mention Kutisker. In the following discussion I will examine Kutisker's interaction with prominent Finnish officials.

\section{Initial contact with Heikki Renvall and Kai Donner}

Kai Donner, a prominent linguist, anthropologist and activist of the Jäger movement, ${ }^{3}$ was the

national career as a financial adventurer. $\mathrm{He}$, too, became the object of antisemitic hate campaigns.

3 The Jägers were Finnish volunteers who received military training in Germany between I9I5 and I9I 8 in order to secure Finland's break from imperial Russia. The Finnish volunteers formed the Royal Prussian 27 th Jäger Battalion, which gained combat experience on the Eastern Front. The battalion returned to Finland in I91 8 in order to form the core of the government troops in the Finnish Civil War. Kai Donner was a member of the activist committee, which organised the Jäger recruitment. first Finnish commandant of the border region between Finland and Bolshevik Russia. Donner noted in his diary on 24 July I 9 I 8 that senator Heikki Renvall had contacted him and asked for advice regarding a Russian Jewish businessman named Kudisker. Evidently this man was Ivan Kutisker; Donner just happened to slightly misspell the name. Kutisker had told Renvall that he was on good terms with a certain Russian commander-in-chief, and Donner concluded that the commander in question was probably General Yevgeny Miller, one of the leaders of the White anti-communist army. Kutisker had said that the commander-in-chief had stolen or otherwise obtained classified documents from Trotsky and Lenin. These documents were supposed to outline deals between Finnish revolutionaries and Russian Bolsheviks, and according to Kutisker the documents predated the Finnish Civil War. Kutisker claimed that the documents had been signed by Oskari Tokoi and Kullervo

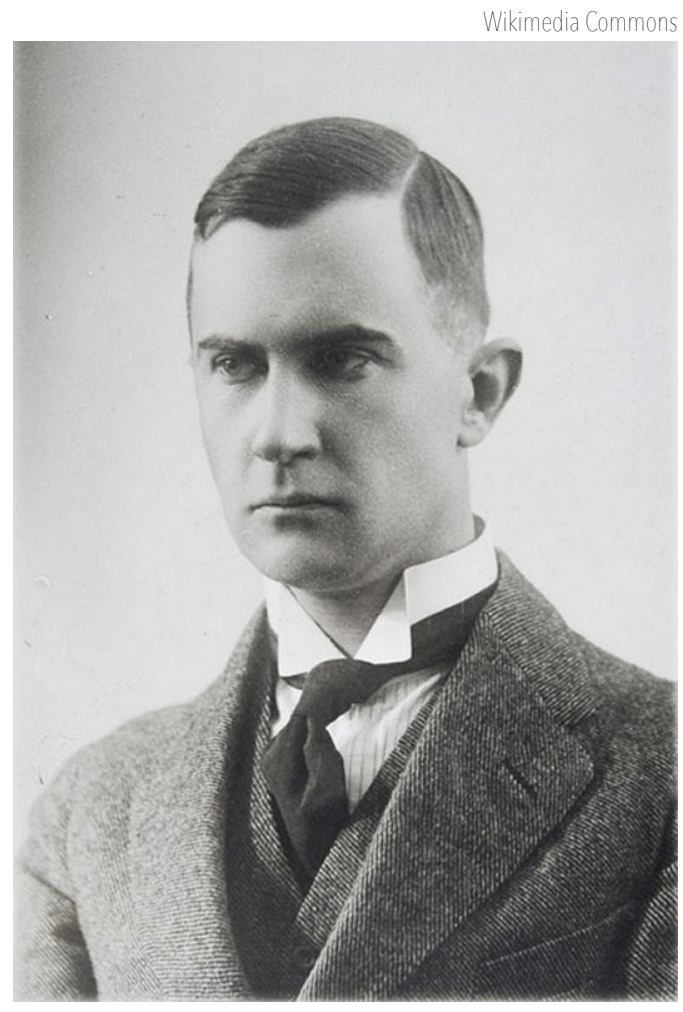

Kai Donner, 1916. 


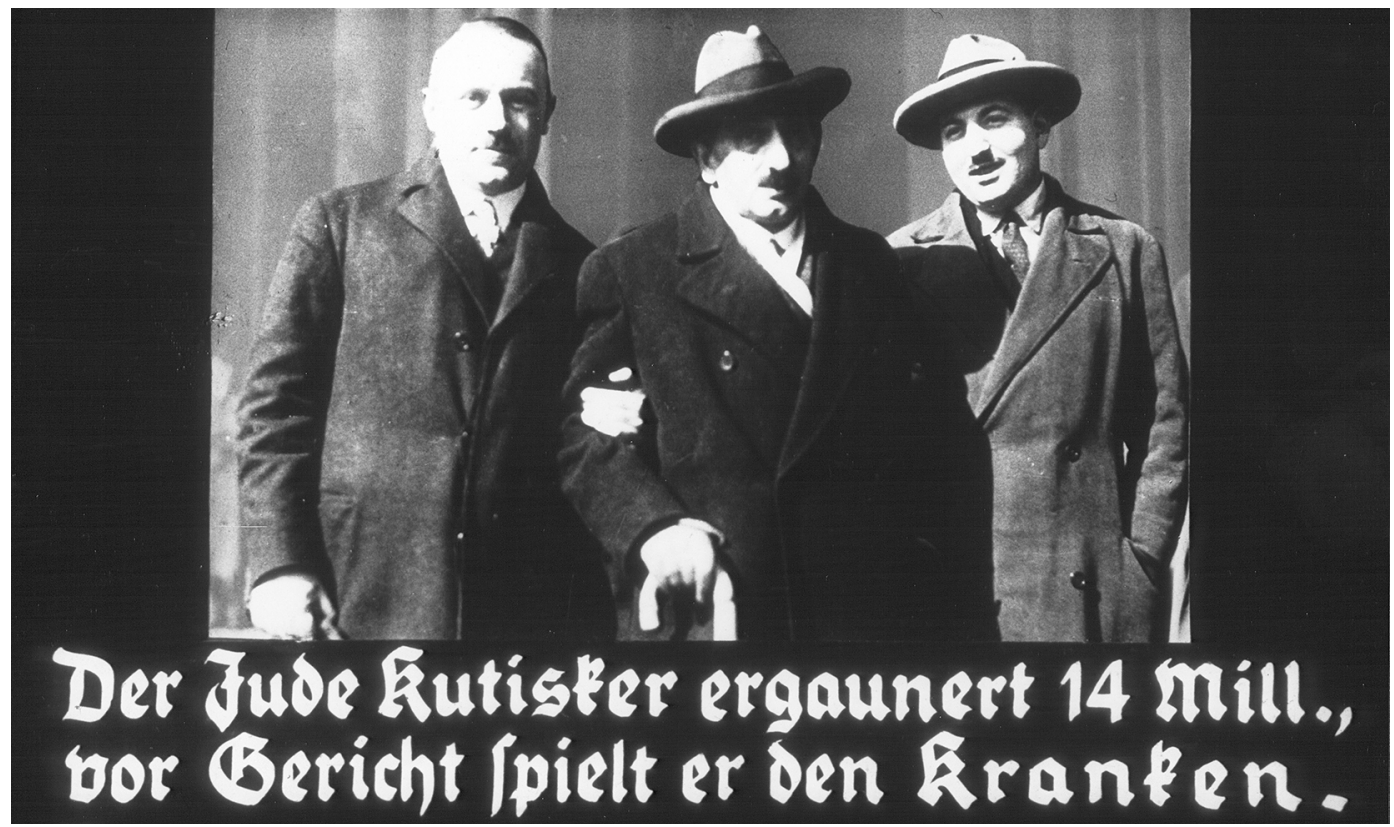

Propaganda slide entitled 'The Jew Kutisker swindles 14 million, he plays sick in court', c. 1933-9. United States Holocaust Memorial Museum, courtesy of Marion Davy.

Manner, leaders of the Finnish Reds, ${ }^{4}$ in October igr7. Kutisker offered to deliver the documents to the Finnish government for a sum of 400,000 rubles, and Renvall was eager to accept the offer. The documents would strengthen the claims of the Finnish government, according to which the Finnish Reds had conspired with the Russian Bolsheviks. Thus the Finnish Civil War could be portrayed as a direct extension of the Russian Revolution.

Donner was a little sceptical about Kutisker's offer. Miller had recently been arrested in Russia, and Kutisker had not made good on his previous promises to obtain the release of jailed Finns in St Petersburg. Neither had he delivered the shipments of oil he had promised, even though he said that he had bribed Zinovyev and 'other leading Jews' in the Bolshevik establishment.

4 The Reds were revolutionary Finnish socialists with popular support among industrial and agricultural workers. They fought against the White government troops in the Finnish Civil War.
Donner concluded that Kutisker could try, and if he succeeded, the papers would well be worth the money. Donner told Renvall that Kutisker was about to cross the border on the following day and that Donner would examine the papers if Kutisker returned with them. 5

However, Kutisker did not return promptly. On I August r9 8 Donner noted in his diary that he had been away from the border for several weeks. Upon his return, he was approached by a large number of people trying to cross the border. He met his counterpart, the Russian border commandant Major Gentsch, at the bridge connecting the two countries. A large number of Jews were also present. The Jews had been running errands for the Finnish senate, but Donner refused to let them cross the border back to Finland since he concluded that they were not really doing anything for the government but rather had been seeking their own

5 RA, Kai Donners samling, Kai Donners dagbok 24.7.I9I 8. 
profit. Donner noted that they were much like Kutisker, who had neither returned to Finland nor made good on his promises to deliver the valuable documents. On 6 August, Donner noted in his diary that a certain Countess Kayserling had tried to act as courier on Kutisker's behalf. The countess had not been allowed to cross the border. She had been infuriated and yelled at the Finnish officials standing on the bridge at the border informing them that she and Kutisker had earned the Finnish state a profit of 5 million rubles through various transactions and that she had also been doing private transactions in foreign currencies on behalf of Senator Otto Stenroth. Donner reported these activities to Helsinki in order to stop what he called 'this Jewish traffic' (denna judetrafik), that is, Jews doing business and running errands across the Russo-Finnish border. ${ }^{6}$

\section{Controversies at the border}

Shortly after this Donner turned in his resignation. After his departure, Kaarle Nestori Rantakari became commandant of the border region. Rantakari was a journalist, banker and politician, who had functioned as chief of police in Vyborg after the Civil War. Rantakari had a colourful political background. After initially flirting with socialism he became active in the Old Finns Party, ${ }^{7}$ articulating vaguely antisemitic views (Roselius 2013: I7). During the Civil War of r9 8 Rantakari went into hiding as the Reds seized power in southern Finland. He chose to hide as a patient in a hospital in Vyborg, playing sick and fearing for his life (Rantakari I 918: 292-316). When government troops defeated the Reds in Vyborg, Rantakari

6 RA, Kai Donners samling, Kai Donners dagbok 6.8.19I8.

7 A Fennoman conservative party advocating appeasement during the period of Russification known as the years of oppression at the turn of the century. was named chief of the local police. Rantakari became commandant of the border region in mid-August i918. Upon taking office he compiled a memorandum concerning problems and irregularities he had perceived at the border and presented the memorandum to his superiors in Helsinki. Rantakari noted with disdain that Jews and Russians had been able to persuade influential people in Finnish government circles to arrange special travel permits for them and contrasted this with the difficulties Finns had in obtaining permits to cross the border in order to return to their native country. Rantakari stressed that he had personally observed this traffic on the border bridge and claimed that a majority of the people coming to Finland were Jews.

This claim stands in contrast with the findings of Max Engman. According to him, Jews were included in a group of 67 former Russian subjects alongside Ukrainians, Poles and Estonians, who came from Russia to Finland between September and December r9r 8. This figure can be compared with the total number of 1962 individuals who came from Russia to Finland during that period (Engman 2008: I 97). The records of people crossing the border thus do not verify Rantakari's claim. According to both Donner and Rantakari, Kutisker crossed the border but his name does not come up in the records. It is hard to determine the number of people who crossed the border with special permits, since they were not entered in the records. Rantakari wrote that Kutisker acted as a diplomatic representative of the Finnish government and that Kutisker had crossed the border almost daily and demanded that the Finnish border officials should give him various forms of assistance. Rantakari further claimed that Kutisker had made great promises, which he had not kept. Rantakari states that he had received reports according to which Kutisker was in fact a Bolshevik commissar. Consequently Rantakari was astonished by the trust Kutisker enjoyed in Finnish government circles. 
Jews played a central role in Rantakari's memorandum. Rantakari claimed that an association for promoting the interests of Russian subjects in Finland was de facto run by Jews, who charged stunning fees for money transfers, currency transactions and handling letters between the two countries. On the whole, Rantakari portrayed Jews in a sinister light as scoundrels, shady businessmen and profiteers who were exploiting the conditions prevailing at the Russo-Finnish border. ${ }^{8}$ This portrayal of Jews as usurers and Shylock-style characters was an example of the use of classical antisemitic clichés (Ahonen 2017: 29). In a letter to his superior, Lieutenant-Colonel Eino Suolahti, ${ }^{9}$ Rantakari made his negative perception of Jews representing the committee of Finns living in Russia clear and called it a mainly Jewish committee, which had gained a bad reputation among ordinary Russians. ${ }^{10}$ In a second letter to Suolahti, Rantakari complained that Jews had started to obtain Ukrainian passports and that 'almost all Jews had been transformed into Ukrainians even though their previous connections with the Ukraine were as minimal as their connections

8 RA, Gränskommendanturens arkiv, 96 Kungörelser, brevkopior och förpassningar samt handlingar rörande diverse ansökningar (I918-I 920). SArk-2285/52, 'Selostus epäkohdista rajalla'.

9 Nick-named Eino Verinen (Bloody Eino) Suolahti was a rightist, monarchist and pro-German officer, who resigned from his post as head of the General Staff Intelligence Department after the German defeat in WWI. During the I93os Suolahti was active in far-right political circles, and during WWII he was Surgeon General of the Finnish army. Heinrich Himmler visited Suolahti's summer residence in 1942.

10 RA, Generalstaben, Avdelning Ie:s övervakningsavdelning, Avdelning IIIe:s övervakningsavdelning, 8: Inkomna brev I9 18, K. N. Rantakaris brev (2 st.) till överstelöjtnant Suolahti 29.9.I 9I 8.

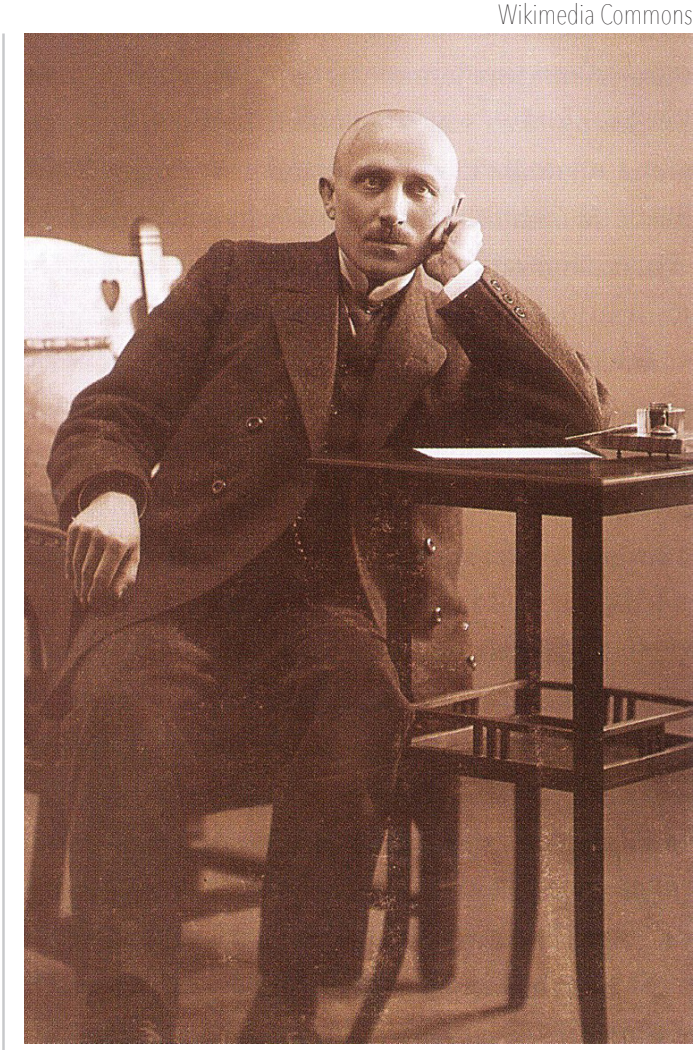

Kaarle Nestor Rantakari, c. 1920.

with New Guinea'.11 Rantakari claimed that Ukrainian passports could be bought illegally at the Ala-Kämp restaurant in Helsinki.

In a secret letter to his superiors, Rantakari further elaborated his views on Kutisker. On his second day in office Rantakari had encountered Kutisker, who presented a letter of recommendation from Senator Renvall that recommended that Kutisker should be allowed to cross the border and travel to Russia since Kutisker was employed by the Trade and Industry Commission in order to take care of vital Finnish interests regarding goods to be imported to Finland. Rantakari stated that Kutisker actually

11 RA, Generalstaben, Avdelning Ie:s övervakningsavdelning, Avdelning IIIe:s övervakningsavdelning, 8: Inkomna brev I 9 1 8, K. N. Rantakaris brev (2 st.) till överstelöjtnant Suolahti 29.9.1918. 
had no intention of crossing the border. Instead Kutisker, Rantakari claimed, wanted to negotiate with his Russian associates and the Russian commandant at the border bridge without interference from the Finnish border guards. Rantakari would have allowed Kutisker to cross the border but he was not willing to arrange the sort of parley that Kutisker was suggesting. According to Rantakari Kutisker had told him that he had been gravely insulted by Second Lieutenant Hovilainen, a Finnish officer at the bridge, and that he would not tolerate Hovilainen's presence. Since Kutisker's demands were against the explicit orders of Rantakari's superiors at the Intelligence Department of the General Staff, and since Kutisker was not willing to act in accordance with the letter of recommendation, Rantakari had told Kutisker that the matter could not be resolved before Rantakari had negotiated with his superiors in Helsinki. ${ }^{12}$

Rantakari questioned both Second Lieutenant Hovilainen and Kutisker regarding the dispute between the two men. Kutisker insinuated that Hovilainen had been expecting bribes in the same manner as the Russians. Kutisker said that he would not bribe Finnish officials since he was acting on behalf of the Finnish government. Hovilainen countered Kutisker's accusations and claimed that Kutisker had been impertinent and refused to follow instructions that were mandatory for all travellers at the border. Rantakari wrote that his own impression was that Kutisker had displayed 'arrogance and intrusiveness characteristic of Jews' and made the much-bothered bridge commandant nervous - hence the harsh treatment. Kutisker had not, however, been taken into custody and he had not been prevented from travelling to Russia. Rantakari further informed his superiors that he had tried to gain a picture of Kutisker's character. Rantakari

12 TYK, K. N. Rantakaris samling, 2.4 (I 4) K. N. Rantakaris brev till generalstaben I E I7.8.I9I8. claimed that he had received negative reports about Kutisker as a banker from his customers and that everyone he had talked to unanimously confirmed that Kutisker was a fraud of the worst kind. Schakoff, a merchant residing in Terijoki, had, according to Rantakari, told him that Kutisker had defrauded him of I 60,000 marks by not delivering goods that Schakoff had paid for. ${ }^{13}$ Schakoff had also asserted that Kutisker had also deceived Moses Skurnik,14 'a Jew from Helsinki', and that Kutisker shifted allegiance, offering his services to anarchists, Bolsheviks and various other factions. These accusations can be seen in the light of the archetypal antisemitic Judas character and the antisemitic portrayal of Jews as traitors (Ahonen 2017: 29). Schakoff had, according to Rantakari, told him to stay as far away from Kutisker as possible. Other people had also, Rantakari alleged, added to Kutisker's negative image; Lieutenant Tapanainen, head of the Border Intelligence Department, had claimed that according to his knowledge Kutisker was a spy. 15

After these deliberations Rantakari decided that Kutisker should be allowed to travel to Russia. Rantakari demanded to be notified

13 Schakoff stated his claims against Kutisker publicly in the official government publication Finlands Allmänna Tidning on 9 December I 918. According to Schakoff, Kutisker had left Finland on 26 October I 91 8. The charges against Kutisker would be pressed even if he did not appear in court or send an attorney to represent him.

14 The controversy between Kutisker and Moses Skurnik unfolded in the press when Kutisker's public letter to Skurnik appeared on the front pages of Helsingin Sanomat (3.5.1 918 , in Finnish), Suomi (3.5.1918, in German), and Hufoudstadsbladet (5.5.191 8, in Swedish). Kutisker claimed that he had made a payment of I 50,000 rubles on behalf of Skurnik and that Skurnik refused to pay back the money.

15 TYK, K. N. Rantakaris samling, 2.4 (I 4) K. N. Rantakaris brev till generalstaben I E I7.8.1918. 
when Kutisker returned so that he could consult with his superiors before Kutisker was allowed to cross the border back to Finland. Kutisker should be given permission to freely conduct discussions with Russian representatives of his own choice, but not without the presence of Finnish officials. Besides the Finnish bridge commandant, two other Finnish officers were assigned to this task since Kutisker had accused the bridge commandant of improper conduct. Kutisker's letters should be promptly sent across the border, but they had to be censored. If the Trade and Industry Commission wanted to engage in uncensored correspondence, the Commission should use other couriers instead of Kutisker. Rantakari informed Kutisker about his decisions. Kutisker threatened to go to Helsinki and complain about his misfortunes at the border. Rantakari underlined that he had acted out of duty and patriotic sentiments, following his conscience. According to his assessment of Kutisker's character, the latter was a crook. Rantakari wrote that he would have suspected Kutisker simply from his highly telling physiognomy. Those kinds of people were familiar to Rantakari from the cafes of St Petersburg, where all kinds of shady characters lurked, trying to cheat people. After his conversations with Kutisker, Rantakari was even more convinced that the Trade and Industry Commission had made an unfortunate mistake and that Kutisker had done considerable damage to Finnish interests. Rantakari sensed that Kutisker posed a serious threat to national security, and consequently he recommended that Kutisker should be deported. 16

This marked the end of Kutisker's brief career as a Finnish government representative. On 20 September I 91 8, Matti Viljanen, director of the Trade and Industry Commission, wrote

16 TYK, K. N. Rantakaris samling, 2.4 (I 4) K. N. Rantakaris brev till generalstaben I E I7.8.19I8. a letter to the Intelligence Department of the General Staff, stating that the Russian brothers G. and M. Siew had been given the task of obtaining army supplies, especially clothes, from St Petersburg. The Bolsheviks were willing to accept cellulose as payment, and the Siew brothers had considerable previous experience in import of cellulose and export of textiles. ${ }^{17}$ They were probably screened in a more thorough manner than Kutisker. The Trade and Industry Commission closely monitored financial crime, and the records of the commission include a list of convicted financial criminals. This list includes the names of 357 people convicted of financial crimes between I9I 8 and I 920. Among these were nine Jews (Abraham Johan Imjack p. I2, Bentzion Skurnik p. 26, M. Steinbock p. 32, Peissah Holopavitsch p. 35, Schemij Bentkover p. 49, Abraham Stiller p. 54, J. Skurnik p. 65, Herman Bernstein p. 86, J. Kjisik p. 99). Abraham Stiller was the only person explicitly listed as Jewish, and two others were referred to as narinkkakauppias, 18 which clearly indicated that they did business in a predominantly Jewish environment. ${ }^{19}$ Apparently

17 RA, Generalstaben, 39: Allmän korrespondens I9I 8-I9I 9, V. M.J. Viljanens brev till Generalstabens avdelning I e:s övervakningsavdelning 20.9.191 8.

18 Narinkkakauppias was a vendor at the marketplace in Helsinki called Narinkka (Swe. Narinken). Narinken was a place where Jews sold second-hand clothes. The name Narinkka/Narinken was derived from the Russian language: на рынке (na rynke), 'at the marketplace'.

19 RA, Handels- och industrikommissionen, Juridiska avdelningen Bb: I Förteckning över dömda i Helsingfors rådstuvurätt (I918-1920). The identification of the persons as Jews is based on the Finnish Jewish genealogical website Meliza's Genealogy www.amitys.com. Some of the names appear there in alternative forms (e.g. Peisach Chalupovitsc פסח חלופוביץ (). See also Ahonen 2017: 78 . 
the Trade and Industry Commission did not attach particular importance to the religious or ethnic affiliation of financial criminals, but it did not completely rule out these considerations. Jews constituted 2.5 per cent of the total of 357 convicted financial criminals, and the Trade and Industry Commission did not seem to harbour any major suspicions regarding Jews. Thus it seems natural that neither Kutisker nor the Siew brothers were judged according to religion or ethnicity. They were seen as trustworthy businessmen capable of serving the Finnish government. This was a striking departure from the antisemitic mode of thought displayed by Donner and Rantakari.

\section{Heikki Renvall: from liberal sentiments to antisemitism}

Senator Heikki Renvall was the man behind Ivan Kutisker's engagement in establishing business connections between Finland and Soviet Russia. Renvall was a liberal of many talents with various prestigious roles in politics, journalism, business and law, and he has been described as a young intellectual who transmitted new ideological and philosophical ideas from continental Europe to Finland around the turn of the century. Among other current events, Renvall followed the Dreyfus affair with keen interest and sympathy (Reenkola 20 I 5: I 43-50, I 85-8). Renvall's biographer Kaarina Reenkola draws a connection between Renvall's sympathies for Dreyfus with his later work for new legislation concerning Jewish civil rights in Finland. Heikki Renvall became a junior member of the Law Drafting Committee in I 907 (Tyynilä I984: I69). Together with two colleagues he worked on legislation concerning the rights of Jews in Finland. This was a thorny issue, which had been debated by the estates during the last decades of the nineteenth century.

Renvall's father, Archbishop T. T. Renvall, had articulated some of the most virulently antisemitic attitudes in this parliamentary debate (Swanström 2016: 79-86). On the other hand, Heikki Renvall also got intellectual input from Leo Mechelin, one of the key liberal politicians in Finland, who was the first politician to suggest that Jews should be given complete equality before the law (Reenkola 2015: 148). Heikki Renvall studied the subject as a professional legal expert and he articulated his preliminary views in a Finnish legal journal. Renvall stated that Swedish legislation from the $\mathrm{I} 78 \mathrm{os}, 20$ which was still in force in Finland, did not in his opinion rule out the possibility for Jews to gain citizenship in Finland. However, this did not, according to Renvall, oblige the Finnish authorities to automatically grant citizenship to Jews who asked for it. Renvall's concluding point was that the Finnish authorities had the right to review each individual case separately and decide according to the national interest Jews could be granted citizenship if it was for the benefit of the country (Renvall I908: I 77).

The Law Drafting Committee gave its proposition one year later, in I909. On the surface the proposition was fairly liberal, giving Jews the possibility of becoming Finnish citizens. Things were, however, complicated by bureaucratic procedures in the application process. The proposition emphasised national considerations: citizenship hinged on the question whether a Jew could prove that he or she was an asset for Finland or not. 21 Jews who were not citizens were allowed to reside only in towns, not in the countryside, and the police were obliged to keep

20 The cornerstone of this legislation was Judereglementet of $\mathrm{I} 782$, which was repealed in Sweden in 1838 but stayed theoretically in force in Finland during the era of Russian rule. On Judereglementet see Valentin I 964: $5^{2-83}$.

21 Similar considerations were applied in Sweden regarding the naturalization of Eastern European Jews. Carl Henrik Carlsson has studied Swedish discriminatory policies 


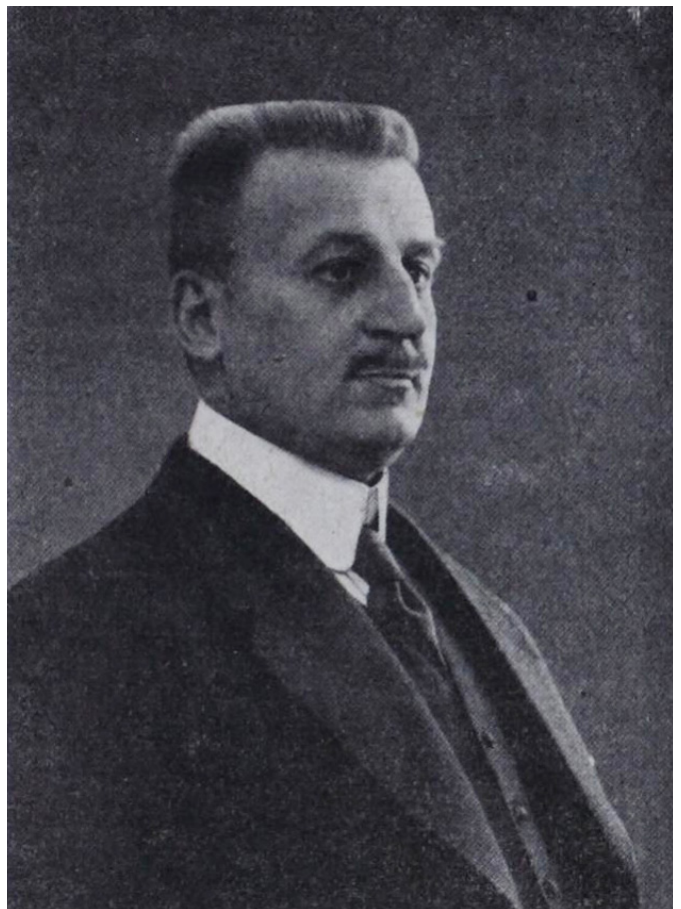

Heikki Renvall. Kaleva: meddelanden till Kalevas agenter 1.4.1916.

records on Jews living in their jurisdiction. Jews who were found guilty of perjury, usury, fraud, forgery, financial crimes or pandering were to be deported from the country (Lainvalmistelukunta I909: 5-6). These regulations were followed by a thorough record of the committee's deliberations. The latter stated clearly that the committee regarded the aforementioned crimes as typical of Jews (Lainvalmistelukunta I 909: 42). It is hard to determine whether these thoughts were originally stated by Renvall or if he just endorsed the views of the other members of the committee. The main point is that Renvall was one of the co-signatories of a proposed law which included clearly antisemitic components. The other co-signatories, Hjalmar Granfelt and

against Eastern European Jews during the period I 860-1920. A disproportionately large percentage of their applications for Swedish citizenship were rejected (Carlsson 2004: 70, 3II-I2).
Frans Oskar Lilius, were not known for any public antisemitic activities, but this does not rule out the possibility that the antisemitic components of the proposed law were a product of their minds. Renvall had evidently been working hard with the proposed law, as he wrote to his wife that he was exhausted when the text was finally ready for print. He mentioned the proposition in a letter to Leo Mechelin, but tried to conceal the actual content of the proposition, stating that Mechelin would probably not want to look at the details (Reenkola 2015: 148-9). Apparently he felt ashamed of producing a proposition which his liberal mentor would find offensive. Owing to political complications the proposed law was not adopted, and the status of Jews living in Finland was only resolved in I9 8 , when Jews were finally given equality before the law.

Renvall's interest in the Jewish people continued after he had finished his work in the Law Drafting Committee. He studied Zionism and Jewish settlement in Palestine, and he showed some understanding and even admiration for the Zionist project, but he doubted the capacity of Jews to engage in serious agricultural efforts. According to Renvall, Jews were city dwellers and a foreign element living on the economic efforts of the surrounding people upon whose economic strength they depended. Renvall thus harboured the classical antisemitic notion of Jews as parasites incapable of independent creative activities. Renvall concluded that Palestine did not offer a future for the Jewish people and that the problems of Eastern European Jews had to be solved in Eastern Europe (Renvall I 9I4: 34). Some antisemites argued that Zionism would solve 'the Jewish problem' by removing the Jews from their European countries of residence, but Renvall was sceptical. He could not picture any solution for the problems of the Jews of Eastern Europe.

Heikki Renvall's political thought presents an enigmatic mix of liberal and antisemitic 
components, and this mix becomes even more intriguing when Renvall's dealings with Ivan Kutisker are taken into account. After Kutisker's departure Renvall's political engagements gradually decreased. Renvall was a Member of Parliament between 1922 and 1924 and presidential elector in r925. Between 1925 and his death in I955 Renvall did not hold any significant political posts. His final major public statement regarding Jews was a comment which he made in a speech in Parliament in r 922 . He stated that he wished that hunger, which was a constant guest in the Soviet paradise, would finish the 'Jewish-Communist state' (Engman 2008: 26). Thus Renvall resorted to classical antisemitic jargon, alluding to Communism as an essentially Jewish phenomenon. This kind of rhetoric was common among the White activist elite of the young Finnish republic. It was spread through publications such as The Protocols of the Elders of Zion. A Swedish translation of the Protocols was published by Rafael Lindqvist in Finland in r 919. A Finnish translation followed in I 920. It is not clear whether Renvall had got the conspiracy theory from the Protocols or if he had received the notion from other sources. Renvall's statement gains additional, complex dimensions, when we take into account that he had employed Ivan Kutisker, a Jewish businessman, in dealings between the Finnish government and the entity he described as the 'JewishCommunist state'. Heikki Renvall's remarks in Parliament suggest that he had completely reverted to the antisemitic thought of his father, Archbishop T. T. Renvall.

\section{Kaarle Nestori Rantakari: covering the traces of antisemitism}

The earliest signs of K. N. Rantakari's animosity against Jews can be traced to the so-called 'Mandelstam affair'. Josef Mandelstam, a Russian Jewish professor at the University of Helsinki, had criticised the Old Finns Party and its policies. Rantakari encouraged student protests against Mandelstam, and the agitated protestors demanded that Jews be expelled from Finland (Jacobsson I95 I: 364-5). Santeri Jacobsson, a prominent Jewish civil rights activist, politician and historian, was familiar with the incident and Rantakari's part in the campaign against professor Mandelstam. Rantakari and Jacobsson were on friendly terms, and Rantakari told Jacobsson that he had prevented a massacre of Jews in Vyborg in the aftermath of the Civil War. According to Rantakari, a group of Jäger soldiers among the government troops had planned to kill the Jews of Vyborg, but Rantakari had ordered their barracks to be locked down on the night of the planned massacre. This action purportedly saved the lives of the Vyborg Jewish community (ibid. 365). Jacobsson assumed that Rantakari had changed his attitude towards Jews, and he accepted Rantakari's account as truthful. Jacobsson later presented Rantakari's account in an authoritative manner in his literary production. Subsequent scholarship has not challenged Rantakari's account (Keskisarja 2013: 35 I-2; Westerlund 2004: I 50), even though there is no other evidence than Rantakari's own words. It would be wise to keep in mind that Rantakari was a political chameleon, navigating according to prevailing winds. As commandant of the border region he definitely expressed antisemitic attitudes both in writing and in actual deeds. When Rantakari was CEO of the Vyborg-based bank Savo-Karjalan Osakepankki, his antisemitic attitudes did not prevent him from doing business with a Jewish banker in Germany (Lembke 20 I 2: 4I, 70).

In the I 930 and the r940s Rantakari was on friendly terms with Bruno Aaltonen, chief of the Finnish security police, who in turn had connections with the Gestapo. Rantakari was well informed about the cooperation of the Finnish and German police agencies. Aaltonen handed over copies of his top-secret correspondence with the Gestapo chief Heinrich Müller to Rantakari 
(Silvennoinen 2008: 355, 390, 400). As chief of press in the Finnish Foreign Ministry Rantakari was invited to a German Nazi-sponsored conference for European journalists, ${ }^{22}$ and before the war he had also been invited to attend Hitler's fiftieth birthday. During the war Rantakari was regarded as a pro-German politician. At the same time Rantakari managed to convince Santeri Jacobsson that he was doing his utmost to save Jewish refugees in Finland from Nazi persecution. When it seemed likely that the refugees would be handed over to the Gestapo, Rantakari advised Jacobsson to contact the British ambassador. Even though Rantakari was on cordial terms with the Germans he did not hesitate to give this piece of advice (Jacobsson I 95 I: 365 ).

Keeping all this in mind we can note that Rantakari was a highly complicated person, who could express various, often contradictory, attitudes and yet retain a pragmatic approach to matters. Another important point to keep in mind is that Rantakari had an enormous social network, which he used to gain information on various political issues. For Jacobsson's part this may have entailed Rantakari merely using Jacobsson as a source of information, while Jacobsson thought that Rantakari was a personal friend and even a philosemite. After the war Rantakari wrote that he had never been an antisemite. He claimed that he had never endorsed hatred against Jews (Rantakari I946: I I). This statement stands in stark contrast to his previous remarks on Jews in general, and Kutisker in particular, during his period as commandant of the border region. After the horrors of the Holocaust Rantakari was convinced that he needed to erase all traces of his previous antisemitism. During

22 TYK, K. N. Rantakaris samling, 9. I Inbjudningskort till Kaarle Nestori Rantakari, II Internationale Journalistentagung der Union nationaler Journalistenverbände, Wien 22 bis 25 Juni I 943 . the war Rantakari had successfully convinced both Nazis and Jews that he was their friend, but when the outcome of the war was clear he distanced himself from his antisemitic past.

\section{Ivan Kutisker in Germany}

After leaving Finland Kutisker moved to Germany in I9r 9. His modus operandi retained some basic features, such as trying to establish political connections, which he harnessed to make money (Weigel 2015: 65). In I 925 he became entangled in a highly publicised and complex financial scandal. 23 Press reports screamed that Reich President Friedrich Ebert and other social democrats and members of the Centre Party had been corrupted by Ostjuden, among them Kutisker, who had used political connections to obtain large loans from the Prussian State Bank, which they were unable to pay back. Martin Geyer writes that 'the names of Barmat and Kutisker became political and cultural code words that were readily used in the contemporary discourse of both the Left and the Right' (Geyer 2010: 212). 'The Barmats and Kutisker came to epitomize in National Socialist propaganda the rats that infested the world - the Eastern Jews who threw off their caftans, shaved their beards, and became cosmopolitan men in other words, they represented the Ewige Jude (wandering Jew) as depicted in the I 94 I film of the same name' (Geyer 2010: 229). Kutisker's name became associated with greed, corruption and crime (see, for example, Keller and Andersen I937: 28, 82). A German parliamentary fact-finding committee portrayed him as a man completely obsessed with money. Later on the Propaganda Ministry, headed by Joseph Goebbels, commissioned Hans Fallada to write a novel about the Kutisker case (Geyer 20 I O: 2 I 5 ).

23 Regarding the complexity of the financial transactions and networks, see the illustration in Klein 201 4: 237. 
During the scandal and his imprisonment before trial Kutisker's health was failing. He died in Berlin on I 3 July I927, one day before the pronouncement of a judgment. As a final insult by his antisemitic detractors, Kutisker ended up in a public autopsy performed by the famous professor Otto Lubarsch before a student audience. Lubarsch came from a Jewish family, but his father raised him in a conservative nationalist Prussian spirit. Lubarsch had been baptised by Adolf Stöcker, one of the founders of German political antisemitism (Lipphardt 2008: $23 \mathrm{I}-2$ ). Lubarsch told his students that he did not hesitate to disclose the name of the deceased. 'It is Iwan Kutisker, a Jew from the East, who was sentenced to five years in prison. At the age of 20 he infected himself with syphilis and he smoked, according to the habits of Eastern Jews, 30 to 40 cigarettes every day' (as quoted in Prüll 2OI I: 483). The disclosure of the name of the autopsy subject led to a scandal and the withdrawal of Lubarsch's license to lecture. ${ }^{24}$

When the Kutisker scandal unfolded in Germany it did not result in any public comments from Kutisker's Finnish contacts. Renvall and Rantakari did not comment on the scandal in any manner, not even in private remarks in diaries or correspondence. Kai Donner made a marginal note in his diary next to the original entries concerning Kutisker: 'Kudisker senare dömd i Berlin för div. bedrägerier' ('Kudisker sentenced later in Berlin for various frauds'). The note is followed by the date Jan 1932 and Donner's initials K. D. Apparently Kai Donner had been thinking about Kutisker and his fate, and probably felt vindicated when his initial suspicions seemed to be proven right.

24 For Lubarsch's own version of the events, see Lubarsch I 93 I: $379^{-85}$.

\section{Conclusions}

Ivan Kutisker's contact persons in Finland were Heikki Renvall, Kai Donner and K. N. Rantakari. Renvall was the first Finnish official to employ the services of Kutisker. Donner and Rantakari were commandants of the border region and they displayed blatantly antisemitic attitudes towards Ivan Kutisker. Renvall had a complex history of previous antisemitic attitudes coupled with more liberal tendencies. As long as he was useful Kutisker could count on being Renvall's protégé. Renvall, Donner and Rantakari came from different political backgrounds. Rantakari was a former party secretary of the Old Finns Party, Heikki Renvall's political background was in the Young Finns Party, and Kai Donner was a Swedish-speaking leader of the Jäger Activists. The origins of Renvall's antisemitism can be traced to his childhood and the influence of his father, Archbishop T. T. Renvall. Renvall tried to adapt himself to the role of the liberal intellectual and take an objective stance regarding the Jewish people, but later he reverted back to his father's antisemitism. The origins of Rantakari's antisemitism are not that easy to determine. Antisemitism was not uncommon within the Old Finns Party, but Rantakari might have received impulses from other quarters as well. He had been observing Jews in St Petersburg and he was ready to judge Kutisker, basing his evaluation simply on Kutisker's physiognomy. This seems to indicate that Rantakari's antisemitism had penetrated deep down to the emotional level of instincts and the subconscious. After the Second World War, Rantakari stated adamantly that he had never been an antisemite. Kai Donner was suspicious of Jews in general, and Kutisker in particular, but he was tempted by the deal which Kutisker offered: the delivery of documents that were supposed to prove the treasonable cooperation between the Finnish Reds and the Russian Bolshevik leadership. 
For Kutisker the encounter with the representatives of the Finnish government seemed to prove two points. I) Wherever he went, there were antisemites, who would meet him with contempt and suspicion. Never mind that some of Kutisker's ventures and schemes were on the wrong side of the law - even if he tried to play according to the rules he would still be a Jew and an object of scorn and harassment. 2) There seemed to be potential in exploiting connections with relatively inexperienced politicians who had recently gained high positions in the new regimes which came to power after the First World War.

Kutisker's brief career as a semi-official Finnish government representative gave him experience which he was able to put to use in Germany in his dealings with German politicians and bankers. Kutisker's development into a symbol and icon of antisemitism gained momentum after he left Finland. His sojourn in Finland has been a hitherto unknown chapter in his life, and by adding the early encounters with Finnish antisemitism to the story of Ivan Kutisker's life, we see before us a picture of a man running the gauntlet from the first insults at the Russo-Finnish border to the ultimate contumely of being publicly dissected and posthumously shamed by Professor Otto Lubarsch, an antisemitic Jewish convert to Christianity.

The antisemitic attitudes displayed by Renvall, Donner and Rantakari indicate that antisemitism was widespread among the Finnish political and military establishment. Antisemitism was not limited to marginal extremist groups - on the contrary, antisemitism influenced the decision-making of high-ranking Finnish officials. Renvall, Donner and Rantakari have so far not been known as antisemites. I have, however, demonstrated that their perceptions and actions were influenced by antisemitism and that their treatment of Ivan Kutisker hinged on a mix of antisemitism and opportunism.
André Swanström is docent of Church History at Åbo Akademi University. He is the author of From Failed Mission to Apocalyptic Admiration: Perspectives on Finnish Christian Zionism (Åbo Akademi University 2007) and Judarna och toleransens psykohistoria i storfurstendömet Finland 1825-1917 (Åbo Akademi 2016) as well as several other monographs and articles. His research interests include the psychohistory of antisemitism, Jewish converts to Christianity in Finland during the nineteenth century, Finnish Christian Zionism, and Finnish military chaplains and SS volunteers in the Second World War.

\section{References}

\section{Archives}

Riksarkivet (RA, National Archives of Finland), Helsinki

Kai Donners samling Kai Donners dagbok

Generalstaben

Avdelning Ie:s övervakningsavdelning, Avdelning IIIe:s övervakningsavdelning 8: Inkomna brev i 9 I 8 39: Allmän korrespondens I9 I 8-r 9 I 9

Gränskommendanturen 96 Kungörelser, brevkopior och förpassningar samt handlingar rörande diverse ansökningar (I9I 8-20)

Handels- och industrikommissionen Juridiska avdelningen

Bb:I Förteckning över dömda i

Helsingfors rådstuvurätt (I9 I 8-1 920)

Turun yliopiston kirjasto (TYK, University of Turku Library)

K. N. Rantakaris samling

\section{Newspapers}

Finlands Allmänna Tidning

Helsingin Sanomat

Hufoudstadsbladet

Suomi

\section{Digital collections}

Meliza's Genealogy, <http://www.amitys.com> (accessed I.I.201 7-4.5.2017) 


\section{Bibliography}

Ahonen, Paavo, 2017.Antisemitismi Suomen evankelis-luterilaisessa kirkossa 1917-1933

(Helsinki, Suomen kirkkohistoriallinen seura)

Carlbäck-Isotalo, Helene, I 997. Att byta erkännande mot handel. Svensk-ryska förhandlingar 1921-1924 (Uppsala universitet)

Carlsson, Carl Henrik, 2004. Medborgarskap och diskriminering. Ostjudar och andra invandrare $i$ Sverige 1860-1920 (Uppsala universitet)

Enckell, Mikael, I 993. I den frågandes själ? Essäer i judiska ämnen (Helsingfors, Söderström \& C:o)

Engman, Max, 2008. Gränsfall. Utväxlingar och gränstrafik på Karelska näset 1918-1920

(Helsingfors, Svenska litteratursällskapet i Finland)

Forsgård, Nils Erik, 2002. Alias Finkelstein. Studier $i$ antisemitisk retorik (Helsingfors, Schildts)

Geyer, Martin H., 2o ro. 'Contested narratives of the Weimar Republic: the case of the "Kutisker-Barmat Scandal" in Weimar Publics/ Weimar Subjects: Rethinking the Political Culture of Germany in the 1920s, ed. Kathleen Canning, Kerstin Barndt and Kristin McGuire (New York, Berghahn Books), pp. 2 I I -35

Hanski, Jari, 2006. Juutalaisviha Suomessa 19181944 (Helsinki, Ajatus Kirjat)

Jacobsson, Santeri, I 95 I. Taistelu ibmisoikeuksista. Yhteiskunnallis-historiallinen tutkimus Ruotsin ja Suomen juutalaiskysymyksen vaiheista (Jyväskylä, Gummerus)

Keller, J., and Hanns Andersen, I 937. Der Jude als Verbrecher (Berlin, Nibelungen-Verlag)

Keskisarja, Teemu, 2013. Viipuri 1918 (Helsinki, Kustannusosakeyhtiö Siltala)

Klein, Annika, 20 I4. Korruption und Korruptionsskandale in der Weimarer Republik (Göttingen, V \& R Unipress)

Lainvalmistelukunta, I 909. Lainvalmistelukunnan ehdotus asetukseksi mooseksenuskolaisista Suomessa perustelmineen (Helsinki, Keisarillisen senaatin kirjapaino)

Laitila, Teuvo, 2OI 4. Uskonto, isänmaa ja antisemitismi (Helsinki, Arator)

Lembke, Hans H., 20 I 2. Bankier, Fälscher, Historiker. Der Weg des Isaac Lewin durch die Geschichte seiner Zeit (Google Books)

Lipphardt, Veronika, 2008. Biologie der Juden. Jüdische Wissenschaftler über "Rasse" und Vererbung 1900-1935 (Göttingen, Vandenhoeck \& Ruprecht)
Lubarsch, Otto, I 93 I. Ein bewegtes Gelehrtenleben. Erinnerungen und Erlebisse, Kämpfe und Gedanken (Berlin)

Muir, Simo, 20 13. 'Modes of displacement: ignoring, understating and denying antisemitism in Finnish historiography' in Finland's Holocaust: Silences of History, ed. Simo Muir and Hanna Worthen (Basingstoke, Palgrave Macmillan), pp. I-30

Prüll, Cay-Rüdiger, 20 I I. 'Science and politics: pathology in Weimar Germany (I 9 I 8-33)' in Weimar Culture and Quantum Mechanics: Selected Papers by Paul Forman and Contemporary Perspectives on the Forman Thesis, ed. Cathryn Carson, Alexei Kojevnikov and Helmuth Trischler (London, Imperial College Press), pp. 475-86

Rantakari, K. N., I 91 8. Vihollisen leirissä punaisen kapinan aikana (Porvoo, Werner Söderström Osakeyhtiö)

- 1946 . 'Sanomalehtimiehen ohdakkeiselta taipaleelta' in Helsingin Sanomalehtimiesyhdistys: Me neekerit. Alastonta totuutta lehtimiehistä ja toimitustyön piiristä (Porvoo \& Helsinki, Werner Söderström Osakeyhtiö)

Reenkola, Kaarina, 20I 5. 'Tabdon jotain maani puolesta tehdä'. Heikki Renvall aatteiden ja ilmiöiden välittäjänä 1900-luvun alun Euroopassa (University of Helsinki)

Renvall, Heikki, ı 908. 'Salliiko Suomen laki mooseksen-uskolaisten päästä Suomen kansalaiseksi?’, Lakimies 6, pp. I 5 I-77

_ I 9 I 4 . 'Juutalaisten kansallinen tulevaisuus', Valvoja, pp. I4-34

Roselius, Aapo, 201 3. Isänmaallinen kevät. Vapaussotamyytin alkulähteillä (Google Books)

Silvennoinen, Oula, 2008. Salaiset aseveljet. Suomen ja Saksan turvallisuuspoliisiybteistyö 1933-1944 (Helsinki, Otava)

Swanström, André, 2016. Judarna och toleransens psykohistoria i storfurstendömet Finland 1825-1917 (Kyrkohistoriska arkivet vid Åbo Akademi)

Tyynilä, Markku, I984. Lainvalmistelukunta 1884-1964 (Helsinki, Suomalainen Lakimiesyhdistys)

Valentin, Hugo, I 964. Judarna i Sverige (Stockholm, Bonniers)

Weigel, Bjoern, 20 I 5. 'Barmat, Sklarek, Rotter, or: the fabrication of the "Jewish Economic Scandal" in I 920 os Berlin' in National Economies: Volks-Wirtschaft, Racism and Economy in Europe Between the Wars (1918-1939/45), ed. Christoph Kreutzmüller, 
Michael Wildt and Moshe Zimmermann

(Cambridge Scholars Publishing), pp. 62-79

Westerlund, Lars, 2004. 'Me odotimme teitä

vapauttajina ja te toitte kuolemaa. Viipurin

valloituksen yhteydessä teloitetut venäläiset'

in Venäläissurmat Suomessa 1914-22, ed.

Lars Westerlund (Helsinki, Valtioneuvoston

kanslia) 